\title{
Behavior and perceptions of hand hygiene practices among dental students
}

\author{
Comportamento e percepção de práticas de higiene das mãos entre os estudantes de Odontologia
}

Eliana Dantas da COSTA ${ }^{1}$

Glaucia Maria Bovi AMBROSANO2

Camila PINELLI ${ }^{3}$

\section{ABSTRACT}

\section{Objective}

To investigate behavior and perception of hand hygiene practices among undergraduate students in a School of Dentistry.

\section{Methods}

The study adopted a qualitative technique called Collective Subject Discourse (CSD). The sample comprised students enrolled in a Public School of Dentistry, in Sao Paulo State, Brazil $(n=54)$. Semi-structured interviews were recorded in a digital voice recorder. Data analysis was carried out by means of a quali-quantitative approach with the help of Qualiquantisoft $₫$ software.

\section{Results}

Students showed adequate knowledge regarding guidelines about hand hygiene practices. However, they considered their procedure gloves as an effective way to avoid crossed-infection, and mentioned inadequate infrastructure of sinks and sometimes lack of consumables undermined their adherence to hand hygiene practices. They reported health professionals and professors at the Institution as being reckless with handwashing, especially before donning gloves or after removal. Students reported the school properly guided them in relation to teaching hand hygiene practices, but they stated they were careless with the recommendations. Students were very concerned if they would hypothetically be treated by professionals who did not wash their hands.

\section{Conclusion}

This study identified some of the hand hygiene compliance failures among dental students. Educational strategies by means of an increase in motivation to perform hand hygiene properly, and by adjusting professor's practices in front of the students would be crucial to improve adherence. Additionally, the improvement on the infrastructure in this institution by means of new washbasins and more available consumables would benefit hand hygiene adherence.

Indexing terms: Behavior. Hand hygiene. Health human resource training. Qualitative research. Perception.

\section{RESUMO}

\section{Objetivo}

Investigar o comportamento e a percepção sobre a prática da higiene das mãos entre acadêmicos de um Curso de Odontologia.

\section{Métodos}

Este estudo adotou a técnica qualitativa Discurso do Sujeito Coletivo (DSC). A amostra foi composta por estudantes matriculados numa Faculdade Pública de Odontologia do Estado de São Paulo, Brasil $(n=54)$. Entrevistas semiestruturadas foram registradas em um gravador digital. A análise dos dados foi realizada por meio de abordagem quali-quantitativa com auxílio do programa Qualiquantisoft@.

\section{Resultados}

Estudantes mostraram conhecimento adequado quanto às diretrizes sobre a prática de higiene das mãos. Porém, consideraram que as luvas de procedimento seriam efetivas para evitar a contaminação cruzada e afirmaram que a infraestrutura inadequada de pias e a falta de materiais de consumo minavam a adesão. Relataram que o comportamento em higiene das mãos de profissionais e de alguns professores era negligente quanto à higiene das mãos, especialmente antes de calçarem luvas e após retirarem. Relataram que a faculdade oferecia ensino para correto treinamento, mas atribuíram a si próprios a postura negligente. Entretanto, apresentaram-se muito preocupados de serem hipoteticamente atendidos por profissionais que não lavassem as mãos.

\section{Conclusão}

Algumas falhas quanto à conformidade com a higiene das mãos entre estudantes de Odontologia foram identificadas. Estratégias educativas, por meio da motivação e do ajuste da conformidade da prática pelos professores seriam fundamentais para aumento da adesão. Adicionalmente, melhorias na infraestrutura nessa instituição, por meio de novas pias e disponibilidade irrestrita de material de consumo beneficiaria a adesão à higiene das mãos.

Termos de indexação: Comportamento. Higiene das mãos. Capacitação de recursos humanos em Saúde. Pesquisa qualitativa. Percepção.

\footnotetext{
${ }^{1}$ Universidade Estadual de Campinas, Faculdade de Odontologia, Departamento de Diagnóstico Oral - Área de Radiologia Odontológica. Av. Limeira, 901, Areião, Caixa Postal 52, 13414-903, Piracicaba, SP, Brasil. Correspondência para / Correspondence to: ED COSTA. E-mail: <elianusp@ yahoo.com.br>.

2 Universidade Estadual de Campinas, Faculdade de Odontologia, Departamento de Odontologia Social. Piracicaba, SP, Brasil.

${ }^{3}$ Universidade Estadual Paulista Júlio de Mesquita Filho, Faculdade de Odontologia, Departamento de Odontologia Social. Araraquara, SP, Brasil.
} 


\section{INTRODUCTION}

The practice of hand hygiene, essential in the process of infection control, is the most important activity to perform in order to diminish cross-infection of pathogens between the caregiver and the patient ${ }^{1-4}$. Although this is simple, there is generally a low level of adhesion, estimated at $40 \%{ }^{2,5-6}$.

In dentistry, adhesion to hand hygiene protocols has also been low ${ }^{2,4,7}$ and is estimated to be lower than $50 \%{ }^{3}$.

The World Health Organization (WHO) recently pointed out the world problem of insufficient practice of hand hygiene in health establishments, and the need for guidelines to be implemented by means of the World Alliance for Patient Safety ${ }^{8}$. In 2009, The Brazilian National Sanitary Vigilance Agency (ANVISA) ${ }^{9}$ published guidance about hand hygiene in health services, adding reinforcement to existent programs.

However, the existence of guidelines does not mean direct cooperation with the task of hand hygiene. Cognitive, social, motivational and behavioral factors and consciousness rising play an important role in adhesion to the practices proposed ${ }^{1,10}$. In this context, three types of psychological influences act on this behavior: habit (learned, automatic behavior), motivation (feelings of aversion, comfort and fear) and planning ${ }^{11}$.

The barriers that preclude correct adhesion to protocols and the strategies to be used in changing this inadequate behavior among health service workers has been investigated, particularly in countries such as the United States and the European Union, but as yet, little is known about them in developing countries ${ }^{12}$.

Qualitative studies have shown the influences that act on individuals in the complex environment of health care to be discovered ${ }^{13}$. In this sense, the qualitative investigation into the topic of hand hygiene has been verified in the literature for the hospital area ${ }^{10}$. However, there is no previous study aimed at investigating hand hygiene practices among dental students in the period of their professional formation.

University education acts on professional behavior, and therefore, academics in Dentistry need to be continually encouraged to be more committed to adhere to the practice of hand hygiene. The aim of this study was to investigate behavior and perception of hand hygiene practices among dental students enrolled at a public university in São Paulo state, Brazil, with interest in improving educational strategies toward this population.

\section{METHODS}

This qualitative study with a cross sectional approach was based on recorded interviews collected among dental students regarding hand hygiene practices. The qualitative strategy was chosen because there is no previous study available, and because it is considered suitable for exploratory studies, in which one seeks to describe, in detail, the causal factors of human behavior that interferes in adhesion to hand hygiene practices in health services ${ }^{14-15}$. In view of the study characteristics, the dental student was considered the subject, and the dental care environment, the locus of actions.

A script of open questions was used. The following topics were covered 1) hand hygiene practice performed in a routine basis for the treatment of dental patients; 2) reflections about the infrastructure available and the desired one, when hand hygiene is performed in the health service, 3) reflections about hand hygiene practiced by health professionals in general, 4) reflections about behavior in hand hygiene practiced by academic colleagues and 5) perceptions about the hypothetic fact of being attended by a dental professional who has not washed his/her hands before donning gloves for the dental procedures.

The data analysis employed the Collective Subject Discourse (CSD) technique according to Lefèvre \& Lefèvre ${ }^{16}$. CSD favors a recovery of the thoughts, values, and beliefs individually internalized via discourse. By means of the CSD it is possible to understand a universe of meanings, motives, aspirations, beliefs, values, and attitudes ${ }^{10,16}$, capable of interfering in the safe practice of hand hygiene.

The Qualiquantisoft ${ }^{\circledR}$ software was used so the analysis of the data involved the selection of "key expressions" from each speech, identifying the "central ideas of each key expression", and creating the "CSD" itself. The "key expressions" are the parts of the speech that best answer each question. "Central ideas" are synthesized descriptions of each meaning that was present in each analyzed speech. The CSD is a combination of similar key expressions and central ideas in a whole discourse synthesis and it is written in the first person singular.

Although the numerical aspect of the final sample is not the fundamental concern of qualitative 
researches ${ }^{16-17}$ and literature has shown that for qualitative studies - in which the object is the understanding of common perceptions and experiences within a relatively homogeneous group of individuals - twelve statements would be enough ${ }^{18}$, an endeavor was made to provide at least 50 volunteers.

A total of 54 volunteers who had been practicing dental care activities in patients at the dental school were individually interviewed. The interviews were conducted by a single researcher, in a private and quiet environment. The statements were recorded with a voice recorder. The audio content was afterwards fully and literally transcribed, and inserted in a computer with the aid of the Qualiquantisoft ${ }^{\circledR}$ software.

Meticulous reading, interpretation and evaluation of the natural speech of collectivity were carried out by two researchers, in order to obtain dental students reflections on the topic of hand hygiene.

The research was previously approved by the Research Ethics Committee of the Institution under Protocol n. 34/09. All participants previously received explanations, and then signed the Term of Free and Informed Consent (TFIC) for the research before participating.

\section{RESULTS}

\section{Sample}

Participants were 22-years-old in average, and females represented $63 \%$ of the sample. Approximately $45 \%$ were third-year students, and the remainder was composed of fourth- and fifth-year students $(27.77 \%$ each).

\section{The Collective Subject Discourse (CSD)}

Results are shown on a summary chart. It contains the questions and the categorical answers obtained after a thorough analysis of the respondents' discourse (Chart 1) according to each question, as it was proposed by Lefèvre \& Lefèvre ${ }^{16}$.

Chart 1. Synthesis of the CSD and categorical answers according to central ideas of 54 participants.

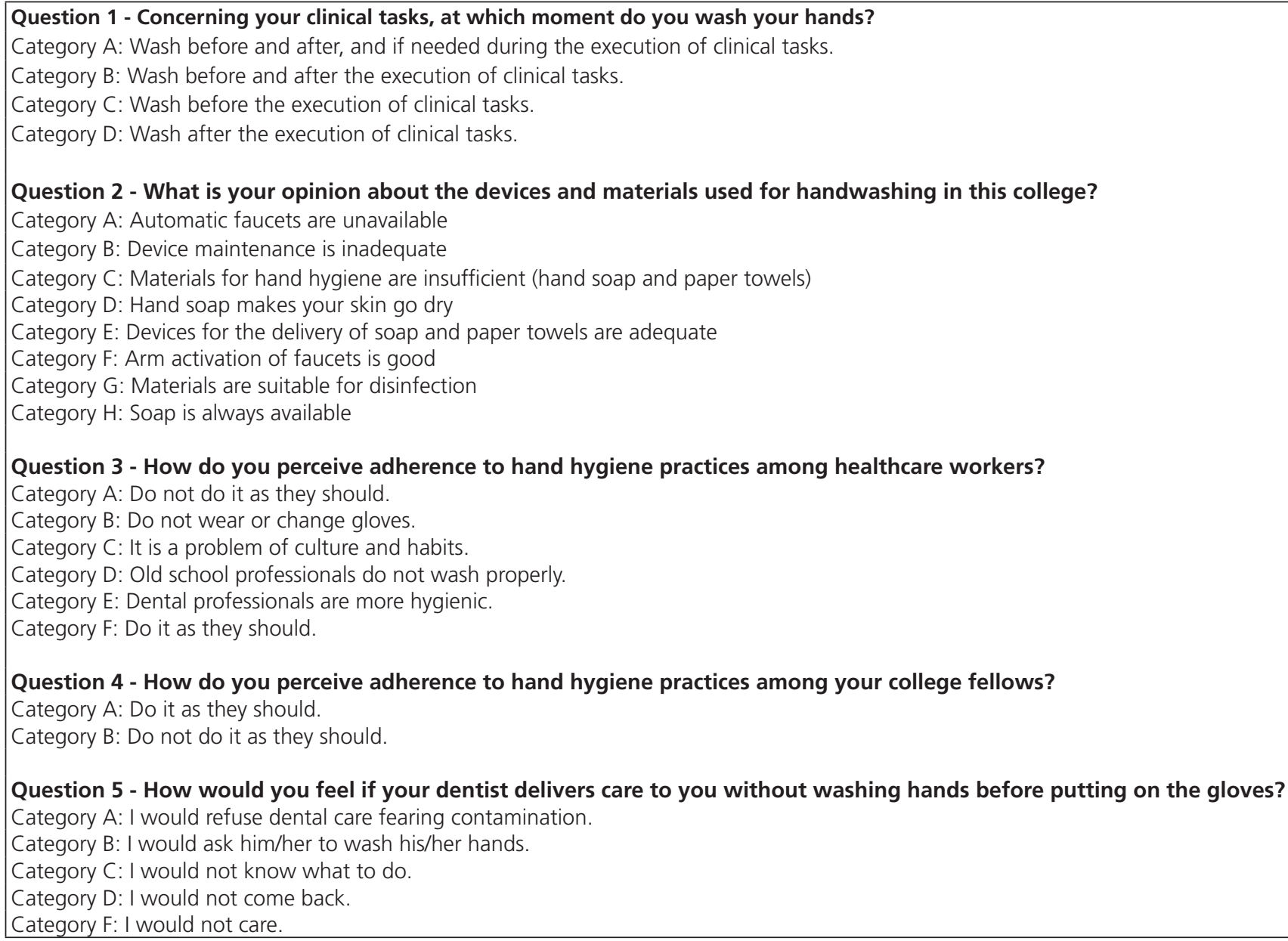

Question 2 - What is your opinion about the devices and materials used for handwashing in this college?

Category A: Automatic faucets are unavailable

Category B: Device maintenance is inadequate

Category C: Materials for hand hygiene are insufficient (hand soap and paper towels)

Category D: Hand soap makes your skin go dry

Category E: Devices for the delivery of soap and paper towels are adequate

Category F: Arm activation of faucets is good

Category G: Materials are suitable for disinfection

Category H: Soap is always available

Question 3 - How do you perceive adherence to hand hygiene practices among healthcare workers?

Category A: Do not do it as they should.

Category B: Do not wear or change gloves.

Category C: It is a problem of culture and habits.

Category D: Old school professionals do not wash properly.

Category E: Dental professionals are more hygienic.

Category F: Do it as they should.

Question 4 - How do you perceive adherence to hand hygiene practices among your college fellows?

Category A: Do it as they should.

Category B: Do not do it as they should.

Question 5 - How would you feel if your dentist delivers care to you without washing hands before putting on the gloves? Category A: I would refuse dental care fearing contamination.

Category B: I would ask him/her to wash his/her hands.

Category C: I would not know what to do.

Category D: I would not come back.

Category F: I would not care. 


\section{DISCUSSION}

\section{Hand hygiene practices in the routine attendance of dental patients}

The following discourse emerged from the speeches: "I wash my hands before attending the patient and after having attended; I always wash my hands at the beginning of attendance, before donning gloves (...)"

Although simply reporting on the standard of hand hygiene is not sufficient to prove conformity with effective practice ${ }^{5}$, the present result showed there was good perception with respect to the recommendations of hand hygiene practices, and it showed that dental students have formal knowledge about this practice.

However, other academics reported they only washed their hands at the beginning of the clinical attendance: "Normally, I wash my hands only at the beginning, before putting on gloves for the procedure (...), before sitting down on the chair, before anamnesis, and before analyzing which procedure I will perform in the patient's mouth".

This habit may be related to the mistaken idea that the gloves completely protect the hands. Gloves are not a completely effective barrier against microorganisms, because they have microscopic imperfections ${ }^{2,4}$, but they do give a false sense of security ${ }^{5,6,19-20}$. Gloves may also contaminate the hands when they are perforated, or when they are removed from the hand $s^{5-6}$ which justifies the need for hand hygiene right after they are removed. In fact, the protocols recommend that the hands should be disinfected before and after contacting patients, and before and after removing the gloves, 2,-7,9,19,21.

From a hospital perspective, the five time intervals for hand hygiene are attributed as follows: 1- before touching a patient, 2- before an aseptic procedure, 3after the risk of exposure to body fluid, 4- after touching the patient, 5-after touching surfaces and objects around the patient 22 .

Vigilance and hospital infection control are attributed to the Commission on Hospital Infection Control - CHIC, or the Biosafety Commission in dental care establishments. This concerns a group of professionals from the Institution itself who apply strategies and issue guidelines for infection control routines during attendance in order to promote the safety of health professionals and patients. These comprise hand hygiene, use of individual protective equipment, prevention of occupational accidents, sterilization of instruments and articles, among others.

In the Dental School investigated in this study, this is an advisory commission to the Executive Board to improve the organization of the health service provided. The resources for implementation of changes are not always available, but it is the Biosafety Commission's responsibility to act at the interface between the administration and users. This is a constant challenge because when routines are established there is a need for changes in paradigms in order to obtain adhesion to the protocols. Another challenge is the maintenance of adhesion to the protocols generated, and the educational and motivational activities do not always reach the desired effect in the long term.

It is suggested that a specific discipline of Biosafety and Infection Control education should be inserted into the curricular structure of the Dental Courses. This would define specific didactic space to improve motivation and reinforce educational aspects regarding hand hygiene practices and other recommendations based on guidelines in infection control in Dentistry, before students have access to clinical environments with patients. The practice of hand hygiene deserves a joint effort between the educational activities of the Biosafety Commission and curricular teaching so that there will be greater relevance in academic training.

\section{Infrastructure and hand hygiene}

With regard to the conditions of hand washbasins and materials used for hand hygiene, criticisms were made and discouraged the use of these items: "I do not know up to which point it is safe. I have already found dirty clogged sinks. They are horrible! There are persons who do not respect and (...) I have seen my classmates wash contaminated instruments in the washbasins we use for washing out hands. (...). I think an automatic activator would be more suitable and there would not be crossinfection on the faucet, (...) so it would be much better, a lot easier and faster (...)."

Another criticism that emerged in the analysis of the discourse was that soap and paper were not adequately replaced: "(...) the replacement of soap, (...) or paper, needs to be improved, because not all the washbasins have these items, and one needs to run around the entire clinic to find them (...) I think this is carelessness on the part of the personnel responsible for replacement." 
The National Sanitary Vigilance Agency (ANVISA), in $2006^{9}$, established that dental establishment must have different washbasins for each handwashing and instrument cleaning. The inadequate use of washbasins for washing contaminated material indicates that some academics do not respect the flow of cleaning, making the washbasin a focus of cross-infection.

Literature shows that the practice of hand hygiene is affected by the accessibility to sanitary installations, presence of washbasins, availability of and access to materials, among other factors 1,5-8,10,19-21,23.

Another study ${ }^{11}$ showed university students in Ghana appeared to be reluctant to wash their hands in unhygienic facilities. It was observed that only six of the 806 students appropriately washed their hands after defecation. Poor soap availability was clearly a constraint factor. Constraining factors were also related to the washroom cleanliness and the tap flow of water. Handwashing behavior was hampered by psychological influences such as feelings of disgust. This is in agreement with the present study.

Despite having correct knowledge about the relevance and the techniques of handwashing behavior, psychological influences can enable or constraint correct practices in health. Knowledge and habit are not enough to the automatization of the process.

Better care needs to be taken for the installation of a sufficient number of specific washbasins for cleaning dental contaminated items. The improvement in the infrastructure and provision of consumables before running out, such as paper and soap, might invite academics to perform hand hygiene.

\section{Perceptions about hand hygiene practiced by health professionals in general}

The perception was that health professionals in general are negligent with regard to hand hygiene: "I think that little attention is paid to handwashing. They put on gloves and simply think that this is enough. Few bother with washing, or if they wash, they do not perform all the correct procedures such as washing between the fingers and on the palm and back of the hand. Even after the 'flu epidemic', when there was a major campaign with alcohol in gel form, I think they began overlooking this care in day to day activities. (...). I am tired of seeing professionals treating patients without wearing gloves, including professors, who also do not wash their hands before donning gloves. I sometimes think they don't even change their gloves. They use the same gloves they were wearing when they attended a previous patient. They look like the nurses who work at the health unit systems, who do not change gloves. So I think this is a great failure."

The perception of handwashing failure is in agreement with the literature, in which there is generally a low level of adhesion among health professionals $s^{1-3,5-7,10,19-20,23-24}$.

The discourse obtained here goes beyond the perception of hand hygiene performed by health professionals in the service in general, and refers to professors, with regard to failures in adhesion to handwashing, and also the habit of not changing contaminated gloves to teach in different patients dental chairs.

Gloves may mistakenly be taken as a substitute for hand hygiene ${ }^{20}$ or as protection of the professional only ${ }^{24}$. A previous study ${ }^{24}$ indicated that various health professionals have admitted to use the same pair of gloves, for long periods of time and in various activities, because they felt to be protected. Non removal of gloves between patients contributes to the transmission of pathogens and cross-infection ${ }^{5,19}$

Another discourse verified was that the older professionals in the work market are not complying with hand hygiene because they graduated a long time ago: "I have perceived that the older ones do not care all that much about hand hygiene. (...). I know a dentist who performs surgery without wearing surgical gloves. I think they don't care all that much, because at that time they didn't wear gloves. I think they pay much less attention than we do".

One notes that there is a belief among the interviewees that the professionals who graduated a long time ago have bad hand hygiene habits. A previous study has indicated that culture has a strong influence of hand hygiene behavior ${ }^{25-26}$.

Another question to be considered is the professional models, in which conformity with hand hygiene is influenced by standards that vary among different groups. It has been seen that doctors are capable of influencing the hand hygiene of other professionals ${ }^{23}$, because they are seen as models ${ }^{24}$. In the dental school, the professional models are attributed to the professor, and he/she becomes the example for his/her students. This is why it is important to encourage good hand hygiene habits in this group, so that they will be followed in professional life. 
From the perspective of psychological influences ${ }^{11}$ this finding is quite interesting. Dental students have the knowledge of the importance of handwashing so they are able to identify the "wrong behavior" of the health professionals, especially their professors. However, such knowledge is not enough to push them to adherence; it has exactly the opposite effect, guiding them to a reckless behavior.

Mariwah et al. ${ }^{11}$ verified that handwashing behavior among university students was affected by the presence of other individuals performing handwashing in the washroom at the same time. Therefore, it is really important not to underestimate the responsibility of the professors as role models in infection control education.

\section{Perceptions about the hand hygiene behavior performed by academic colleagues}

As regards the perception about hand hygiene among faculty colleagues, the most frequent discourse was the following: "I perceive that the majority follow the rules correctly, because, as we are at the dental school, in a climate of learning and responsibility, yes, I see everyone washing their hands. I never saw anyone skipping this stage. They are conscious of the importance, because everyone is concerned about washing their hands, before and after they have finished treatment. I wash my hands with soap, and sometimes I rub on antiseptic handwash. I don't know if I am washing hands correctly, but at least I do wash my hands. If I don't wash my hands, it makes me sick and I am afraid of infection control (...) especially because we have the professors instructing, making us aware of it. So I think there is great adhesion to handwashing by my colleagues."

In this speech students seem to demonstrate the importance of habit learned in college and the challenge they face with regard to "disgust" and "fear of infection control", in order to avoid cross-infection.

Faculties in the field of health and Dentistry are responsible for teaching the principles of infection control, promoting adhesion to guidelines. Lack of professional guidance and lack of good role models are connected with lower levels of compliance with hand hygiene ${ }^{7}$.

Findings of the present investigation also showed a completely different opinion regarding colleagues in the dental school who did not wash their hands appropriately: "I think they don't wash their hands frequently. I perceived a lack of hygiene. I think there is a lack of habit to wash hands before procedures and mainly at the end, before leaving the clinic. But it is not because of lack of instruction. In the faculty I believe the instruction on this issue is very adequate. Some friends forget because of haste, laziness, anxiety or distraction, or because they think it is not important. (...). I think there is still lack of consciousness rising on their part.

Adhesion to hand hygiene is a voluntary and individual act that depends on the decision of each professional, and in this sense it is influenced, among other factors, by the inherent complexity of the professional who provides care ${ }^{21}$.

\section{Perceptions about being attended by someone who has not washed his/her hands}

Three different discourses were obtained. The first of these indicates disgust at being attended by a professional who has not washed his/her hands: "I wouldn't like to be attended like this, I would feel sick, I would feel distrusted about the attendance, and would not feel very comfortable, because hands convey a great deal of contamination. (...). Apart from this, the glove is porous and it is a very fragile and thin physical barrier. And his hand, beneath the glove, could have a stack of bacteria. If it perforated, something could happen (...). So, I would not allow him to perform the treatment. ( ) I began to pay more attention to what other professionals do. (...)."

Other interviewees related that they asked the professional to wash his/her hands: "I have been through this experience, I didn't know what to do, I didn't know whether to interrupt or say to him: "oh, aren't you going to wash your hands?", or if I should keep quiet and not come back again (...). I think it is carelessness about the patient's health (...).

Another discourse that arose was: "I think I would feel ok, because if I didn't see, I wouldn't know the difference. If he were wearing gloves at the time, I wouldn't worry much. I don't think I have any problem about him not having washed his hands before. It wouldn't bother me, because it's the same in a restaurant where one doesn't know what happens in the kitchen (...)."

Although it is important for the prevention of dissemination of diseases during dental office routines, hand hygiene is not always performed with the due strictness, and because gloves may have unperceived perforations, they may allow the propagation of bacteria from the operator's hands to the tissues of patients ${ }^{27}$. 
In a study conducted by Jang et al. ${ }^{24}$, health professionals mentioned that they would feel ashamed if a patient asked whether they had washed their hands, and if in fact they had not done so. This situation causes embarrassment to both parties, patient and professional, leading to distrust and threatening the well-being of the person receiving care, particularly because lay persons in general know that health professionals must wash their hands in order to attend them.

The perception that the health service would be like that of a restaurant, suggests that the care provided is the same. But it is not, because the consequence of poor hygiene in health services results in cross-infection and the use of gloves reduces the risk of contamination. Nevertheless, in spite of offering a means of protection, they create a comfortable and humid environment for the proliferation of microorganisms, and increase the transitory microbiota. Therefore, handwashing is essential for eliminating it and diminishing the resident microbiota ${ }^{4}$.

A previous study investigated the cultural determinants of behavior in infection control, and found that successful strategies are those that are formulated in accordance with the culture in which they are implemented (Hofstede's model of cultural dimensions) and the methods of motivation are influenced by cultural habits $^{26}$. Thus, training and education in hand hygiene and biosafety practices need complementary studies to the present one, in order to know the cultural determinants and the beliefs among Dental students.

\section{CONCLUSION}

This study investigated behavior and perception of hand hygiene practices among dental students. The

\section{REFERENCES}

1. Kelcíkova S, Skodova S, Straka S. Effectiveness of hand hygiene education in a basic nursing School curricula. Public Health Nurs. 2012 Mar-Apr;29(2):152-9. doi: 10.1111/j.15251446.2011.00985.x

2. Vega OG, Janus C, Laskin DM. Hand-washing knowledge and practices among dentists and dental specialists. Quintessence Int. 2012;43(5):429-34.

3. De Amorim-Finzi MB, Cury MV, Costa CR, Dos Santos AC, De Melo $\mathrm{GB}$. Rate of compliance with hand hygiene by dental healthcare personnel $(\mathrm{DHCP})$ within a dentistry healthcare first aid facility. Eur J Dent. 2010; Jul;4(3):233-7. use of the technique of the Collective Subject Discourse made it possible to detect some of the underlying aspects that prevented students from handwashing. Although the study was conducted in a single teaching establishment, it is probable that results obtained here would also be found among other academics at other public universities. Dental students showed appropriate knowledge, however psychological influences hampered adhesion, even when scientific knowledge was appropriate. An educational strategy that acts upon motivational basis must be performed, not only for the dental students but also for their professors, and managers at the Institution, as these managers need to improve infrastructure of washbasins and availability of consumables. Attitudes of professors or even from their own colleagues at the dental school bear weight in order to make the working routine safe, improving patient safety.

\section{ACKNOWLEDGEMENTS}

The authors thank FAPESP - "Fundação de Amparo à Pesquisa do Estado de São Paulo" (Foundation of Support for Research of the State of São Paulo) for the financial support provided for the scientific initiation project (2009/15191-0).

\section{Collaborators}

ED COSTA was responsible for conducting the interviews, transcription of statements, analysis and interpretation of data; bibliographic update, discussion and article writing. GMB AMBROSANO contributed to the review and critical analysis of the content of the article. C PINELLI was responsible for the design and planning; introduction; analysis and interpretation of data; discussion and article writing.

4. Myers R, Larson E, Cheng B, Schwartz A, da Silva K, Kunzel C. Hand hygiene among general practices dentists. A survey of knowledge, attitudes and practices. J Am Dent Assoc. 2008;139(7):948-57. doi: 10.14219/jada.archive.2008.0282

5. Boyce JM, Pittet D. Guideline for hand hygiene in health-care settings. Recommendations of the Healthcare Infection Control Practices Advisory Committee and the HICPAC/SHEA/APIC/IDSA Hand Hygiene task Force. Am J Infect Control. 2002;30:S1-46.

6. John M. Hand hygiene: washing and disinfection. J Can Dent Assoc. 2000;66:546-47.

7. Tipple AFV, Mendonça KM, Melo MC, Souza ACS, Pereira MS, dos Santos SLV. Higienização das mãos: o ensino e a prática entre graduandos na área de saúde. Acta Sci Health Sci. 2007;29:10714. 
8. World Health Organization. WHO guidelines for hand hygiene in health care. Geneva, Switzerland: World Health Organization; 2009.

9. Agência Nacional de Vigilância Sanitária. Higienização das mãos em serviços de saúde [citado 2015 Jun 26]. Disponível em: <http:// www.anvisa.gov.br/hotsite/higienizacao_maos/apresentacao.htm>.

10. Joshi SC, Diwan V, Tamhankar AJ, Joshi R, Shah H, Sharma M, et al. Qualitative study on perceptions of hand hygiene among hospital staff in a rural teaching hospital in India. J Hosp Infect. 2012;80(4):340-4. doi: 10.1016/j.jhin.2011.12.017

11. Mariwah S, Hampshire K, Kasim A. The impact of gender and physical environment on the handwashing behaviour of university students in Ghana. Trop Med Int Health. 2012;17(4):447-454. doi: 10.1111/j.1365-3156.2011.02950.x

12. Yuan $C T$, Dembry LM, Higa $B$, Fu $M$, Wang $H$, Bradley $E H$. Perceptions of hand hygiene practices in China. J Hosp Infect. 2009;71:157-162. doi: 10.1016/j.jhin.2008.09.017

13. Forman J, Creswell JW, Damschroder L, Kowalski CP, Krein SL. Qualitative research methods: Key features and insights gained from use in infection prevention research. Am J Infect Control. 2008; 36:764-71. doi: 10.1016/j.ajic.2008.03.010

14. Patton MQ. Qualitative research and evaluation methods. 3rd ed. Thousand Oaks, CA: Sage Publications; 2002.

15. Sofaer S. Qualitative methods: what are they and why use hem? Health Serv Res. 1999 Dec;34(5 Pt 2):1101-18.

16. Lefèvre $F$, Lefèvre $A M C$. $O$ discurso do sujeito coletivo: um novo enfoque em pesquisa qualitativa (Desdobramentos). Caxias do Sul: Educs; 2003.

17. Crossley ML. A qualitative exploration of dental practioner's knowledge, attitudes and practices towards HIV+ and patients with other 'high risk' groups. Br Dent J. 2004;197(1):21-6. doi: 10.1038/ sj.bdj.4811412

18. Guest G, Bunce A, Johnson L. How many interviews are enough? An experiment with data saturation and variability. Field Methods. 2006;18:59-82.

19. Cruz EDA, Pimenta FC, Palos MAP, Silva SRM, Gir E. Higienização de mãos: 20 anos de divergências entre a prática e o idealizado. Cienc Enferm. 2009:15:33-38.
20. Barrett $R$, Randle J. Hand hygiene practices: nursing students' perceptions. J Clin Nurs. 2008;17(14):1851-57. doi: 10.1111/j.1365-2702.2007.02215.x

21. Neves ZCP, Tipple AFV, Souza ACS, Pereira MS, Melo DS, Ferreira LR. Hand Hygiene: The impact of incentive strategies on adherence among healthcare workers from a newborn intensive care unit. Rev Latino-am Enfermagem. 2006;14:54652.

22. Sax H, Allegranzi B, Charaïti MN, Boyve J, Larson E, Pittet D. The world Health Organization hand Hygiene observation method. Am J Infect Control. 2009;37:827-34. doi: 10.1016/j. ajic.2009.07.003

23. Erasmus V, Brouwer W, Beeck EF, Oenema A, Daha TJ, Richardus $\mathrm{JH}$, et al. A qualitative exploration of reasons for poor hand hygiene among hospital workers: lack of positive role models and of convincing evidence that hand hygiene prevents crossinfection. Infect Control and Hosp Epidemiol. 2009;30(5):415419. doi: $10.1086 / 596773$

24. Jang JH, Wu S, Kirzner D, Moore C, Youssef G, Tong A, et al. Focus group study of hand hygiene practice among healthcare workers in a Teaching Hospital in Toronto, Canada. Infect Control Hosp Epidemiol. 2010;31:144-150. doi: 10.1086/649792

25. Allegranzi B, Memish ZA, Donaldson L, Pittet D. Religion and culture: Potential undercurrents influencing hand hygiene promotion in health care. Am J Infect Control. 2009;37:28-34. doi: 10.1016/j.ajic.2008.01.014

26. Borg MA. Lowbury Lecture 2013. Cultural determinants of infection control behaviour: understanding drivers and implementing effective change. J Hosp Infect. 2014;86(3):1618. doi: 10.1016/j.jhin.2013.12.006

27. Serratine AC, Prates G, Meurer HS. Avaliação da eficácia de quatro protocolos de higienização das mãos, utilizados em serviços de saúde. Rev Assoc Paul Cir Dent. 2010;64(5):385-90.

Received on: 17/10/2015

Final version resubmitted on: 19/6/2016

Approved on: 8/7/2016 